\title{
The effect of low-glucosinolate rapeseed meal in diets with multi-enzyme supplement on performance and protein digestibility in broiler chicks
}

\author{
M. Toghyani ${ }^{1,3}$, A. Mohammadsalehi ${ }^{1}$, A. Gheisari ${ }^{2}$ \\ and S.A. Tabeidian ${ }^{1}$ \\ ${ }^{1}$ Department of Animal Science, Islamic Azad University, \\ Khorasgan (Isfahan) Branch \\ 81595-158 Isfahan, Iran \\ ${ }^{2}$ Department of Animal Science, Isfahan Agricultural Research Centre \\ 81785-199 Isfahan, Iran
}

(Received 24 July 2008; revised version 19 November 2008; accepted 20 March 2009)

\begin{abstract}
Three hundred and eighty-four day-old Ross broiler chicks were used in a completely randomized experimental design with $4 \times 2$ factorial arrangements using four rapeseed meal (RSM) levels with and without a multi-enzyme preparation. RSM levels included: A: control (without RSM); B: 5, 10 and $15 \%$; C: 10, 15 and 20\%; D: 15, 20 and 25\% RSM in starter, grower and finisher periods, respectively. Body weight gain and feed conversion ratio in treatments $\mathrm{B}$ and $\mathrm{C}$ were similar to controls, but in treatment $\mathrm{D}$, weight gain decreased and FCR increased $(\mathrm{P}<0.05)$. Feed intake of broilers was not affected by different levels of RSM ( $>0.05)$. Enzyme supplementation had no significant effect $(\mathrm{P}>0.05)$ on growth performance but resulted in a significant increase in ileal digestibility of protein $(\mathrm{P}<0.05)$. Feeding high levels of RSM (Treatment $\mathrm{D})$ significantly increased liver and gizzard weights and decreased abdominal fat $(\mathrm{P}<0.05)$.
\end{abstract}

KEY WORDS: broiler, rapeseed meal, enzyme, performance, protein digestibility

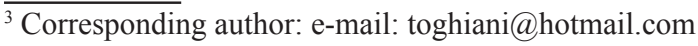




\section{INTRODUCTION}

Rapeseed meal (RSM), called also canola meal (CM), is used as a protein supplement in feeding livestock and poultry. RSM has a protein content about $35-40 \%$ and a physiologically suitable amino acid combination, but the digestibility of some amino acids is lower than in soyabean meal (SBM) (Roth-Maier et al., 2004). Different replacement levels of SBM with RSM have been suggested by researchers (Janjecic et al., 2002; Mushtaq et al., 2007; Tripathi and Mishra, 2007). However, RSM contains nutritionally unfavourable substances such as glucosinolates, sinapin, tannin and phytate, indigestible oligosaccharides, and non-starch polysaccharides (NSP) (Kocher et al., 2000).

In cereal grains, such as wheat and barley, high concentrations of soluble NSP raise digesta viscosity, leading to reduced starch, lipid and protein digestion. The presence of NSP may adversely affect the performance of broiler chickens fed high levels of RSM. However, the addition of commercial enzyme products to wheat- or barley-based broiler diets generally results in a significant improvement in performance and protein digestibility (Annison and Choct, 1991). There is only limited information available on the anti-nutritive effects of RSM and the ability of commercial enzyme products to degrade these components. The addition of a commercial enzyme cocktail that is high in polygalacturonase to a laying hen diet containing $40 \% \mathrm{CM}$ resulted in a significant increase in NSP digestibility (Slominski and Campbell, 1990); however, those researchers made no reference to any improvement in laying performance or egg production. Meng et al. (2005) reported that addition of a multicarbohydrase enzyme supplement to a broiler diet based on wheat, SBM and CM resulted in significant improvement in protein, starch and NSP digestibility and, consequently, improved growth performance.

The current study investigated the effects of cumulative levels of RSM with or without a commercial multi-enzyme preparation on the performance and crude protein digestibility of broiler chicks.

\section{MATERIAL AND METHODS}

\section{Birds and diets}

RSM was purchased from a local oil extraction company. The protein content was $37 \%$, that of glucosinolates, $8.3 \mu \mathrm{mol} / \mathrm{g}$, determined by the HPLC method described by Kaushik and Agnihotri (1999). In total, 384 day-old Ross 308 female broiler chicks were randomly assigned to 8 dietary treatments in 32 pens with 4 replicates in a completely randomized design with $4 \times 2$ factorial arrangements with four RSM levels and two enzyme levels. RSM levels included: A: control 
(0\% RSM ); B: 5, 10 and $15 \%$ RSM; C: 10, 15 and 20\% RSM and D: 15, 20 and $25 \%$ RSM, in starter, grower and finisher diets, respectively. These levels of RSM were used with or without $(1 \mathrm{~g} / \mathrm{kg})$ multi-enzyme preparation. The commercial multi-enzyme contained; U/gm: phytase 2500, cellulase 5000, xylanase 1000 , $\beta$-glucanase 2500 , amylase 10000 , lipase 2500 and protease 2500 , according to the producer's declaration. Diets were formulated to be isocaloric and isonitrogenous in the starter (0-11 d), grower (11-28 d) and finisher periods (28-42 d) and to meet bird requirements according to the recommendations of the Ross Broiler Manual (2002) (Table 1). All diets were formulated to have at least the same level of digestible lysine and methionine + cysteine as the control treatment, using digestibility as reported by NRC (1994). All diets were fed in mash form throughout the 6-week experimental period. The birds had free access to water and feed and were maintained under continuous light. The environmental temperature in the house was initially established at $32^{\circ} \mathrm{C}$ and was gradually reduced to $22^{\circ} \mathrm{C}$ by week 6 .

\section{Sample collection}

Body weight and feed intake were monitored at 11, 28 and 42 days of age, using pens as the experimental units. Before weighing, the birds were fasted for 4 $h$. Mean body weight, feed intake and feed conversion ratio were used to determine growth performance. At $42 \mathrm{~d}$, two birds, close to pen mean body weight, from each pen were individually weighed, slaughtered, and weights of the heart, liver, pancreas, gizzard and abdominal fat were determined.

In order to determine the protein digestibility of diets, $3 \mathrm{~g} / \mathrm{kg}$ chromic oxide were added to the diet for 5 days and on days 42, two birds were randomly selected from each replicate and killed by cervical dislocation. The contents of the ileum (from Meckel's diverticulum to $1 \mathrm{~cm}$ above the ileo-caecal junction) were collected. The ileal digesta samples were frozen, freeze dried, ground, and analysed for nitrogen, and chromic oxide to determine protein digestibility.

\section{Chemical analysis}

Feed and ileal digesta samples were analysed for chromic oxide using the procedure described by Fenton and Fenton (1979). Nitrogen was determined by the Kjeldahl method and the protein contents were calculated using the multiplication factor of 6.25. The following equation was used for the calculation of ileal nitrogen digestibility:

ileal nitrogen digestibility (\%) $=\left\{1-\left[\left(\mathrm{Cr}_{2} \mathrm{O}_{3} \%\right.\right.\right.$ diet $/ \mathrm{Cr}_{2} \mathrm{O}_{3} \%$ digesta $)$

$\times(\mathrm{N} \%$ digesta $/ \mathrm{N} \%$ diet $)]\} \times 100$ 


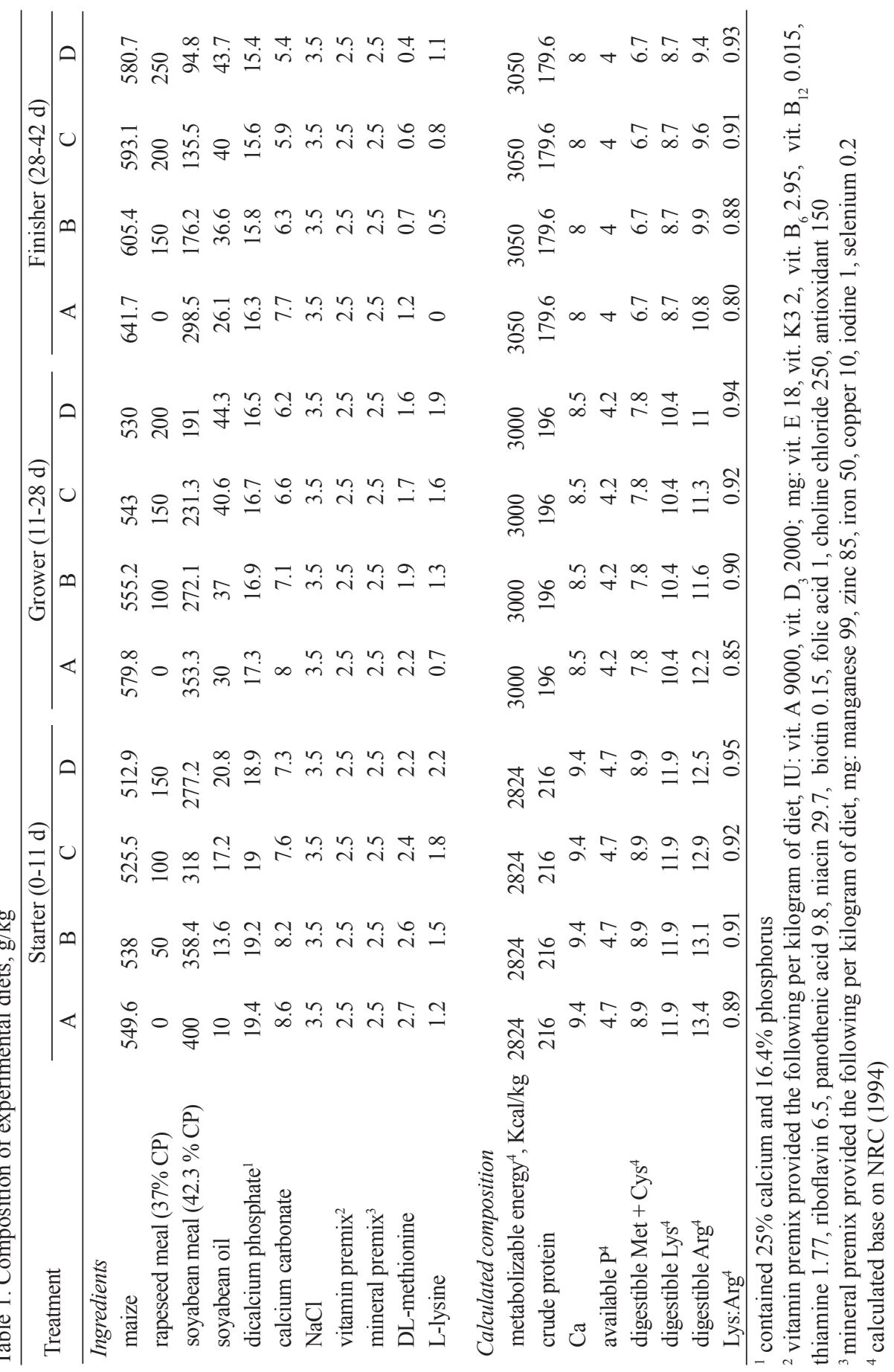




\section{Statistical analysis}

Data were analysed using the general linear model procedure of SAS (1997). Significant differences $(\mathrm{P}<0.05)$ among treatment means were determined using Duncan's new multiple range test.

\section{RESULTS}

Growth performance results of broiler chicks fed different levels of RSM with or without multi-enzyme supplementation measured over a 6-wk period are presented in Table 2. Body weight gain and feed conversion ratio of broiler chickens were significantly $(\mathrm{P}<0.05)$ affected by different levels of RSM in diets.

Table 2. Growth performance of broiler chickens fed different levels of $\operatorname{RSM}^{1}$ with (+) or without (-) multi-enzyme supplementation ${ }^{2}$ (measured over a 6-wk period; 0 to $42 \mathrm{~d}$ of age)

\begin{tabular}{|c|c|c|c|c|c|}
\hline Treatments & Enzyme & $\begin{array}{l}\text { Feed intake } \\
\text { g/bird/day }\end{array}$ & $\begin{array}{l}\text { Body weight gain } \\
\text { g/bird/day }\end{array}$ & $\begin{array}{c}\text { FCR } \\
\mathrm{g} \text { feed/g gain }\end{array}$ & $\begin{array}{c}\text { Ileal protein } \\
\text { digestibility, \% }\end{array}$ \\
\hline \multicolumn{6}{|l|}{ A } \\
\hline & - & 89 & 52 & 1.71 & 64.2 \\
\hline & + & 89.5 & 52.5 & 1.71 & 66.6 \\
\hline \multicolumn{6}{|l|}{$\mathrm{B}$} \\
\hline & - & 87.4 & 51 & 1.71 & 51.7 \\
\hline & + & 89.4 & 50.1 & 1.78 & 53.1 \\
\hline \multicolumn{6}{|l|}{$\mathrm{C}$} \\
\hline & - & 88.8 & 49.6 & 1.79 & 52.2 \\
\hline & + & 89.6 & 50.6 & 1.77 & 54.1 \\
\hline \multicolumn{6}{|l|}{$\mathrm{D}$} \\
\hline & - & 89.5 & 48.9 & 1.83 & 49.6 \\
\hline & + & 89.8 & 48.3 & 1.86 & 51.6 \\
\hline Pooled SEM & & 1.69 & 1.78 & 0.05 & 1.32 \\
\hline \multicolumn{2}{|c|}{ Source of variation } & \multicolumn{4}{|c|}{ Probability } \\
\hline \multicolumn{2}{|l|}{ RSM levels } & NS & $*$ & $*$ & $* *$ \\
\hline \multicolumn{2}{|l|}{ enzyme } & NS & NS & NS & $*$ \\
\hline \multicolumn{2}{|c|}{ RSM levels $\times$ enzyme } & NS & NS & NS & NS \\
\hline \multicolumn{6}{|c|}{$\begin{array}{l}\text { 1-A control ( } 0 \% \text { RSM in starter, grower and finisher); B - 5, } 10 \text { and } 15 \% \text { RSM in starter, grower } \\
\text { and finisher, respectively; C - 10, } 15 \text { and } 20 \% \text { RSM in starter, grower and finisher, respectively; } \\
\text { D - 15, } 20 \text { and } 25 \% \text { RSM in starter, grower and finisher, respectively }\end{array}$} \\
\hline
\end{tabular}


Body weight gain and FCR in treatments B and C were similar to the control, but broilers fed high levels of RSM (Treatment D) had lower body weight gain than others. Feeding high levels of RSM (Treatment D) resulted in a higher FCR $(\mathrm{P}<0.05)$. Different levels of RSM had no significant effect on feed intake by broiler chickens.

Enzyme supplementation had no significant effect $(\mathrm{P}>0.05)$ on growth performance of broilers. Protein digestibility of diets decreased significantly $(\mathrm{P}<0.01)$ by increasing levels of RSM in diets (Table 2). Enzyme supplementation resulted in a significant increase in ileal digestibility of protein $(\mathrm{P}<0.05)$. The addition of the multi-enzyme preparation improved protein digestibility for all the diets (control and RSM diets).

The effects of different levels of RSM and enzyme supplementation on carcass characteristics of broiler chicks are shown in Table 3. Abdominal fat, liver and gizzard weight were significantly affected by different levels of RSM in

Table 3. Carcass traits of broiler chickens (percentage of liveweight) fed different levels of RSM ${ }^{1}$ with (+) or without (-) multi-enzyme supplementation ${ }^{2}$ (measured at $42 \mathrm{~d}$ of age)

\begin{tabular}{|c|c|c|c|c|c|}
\hline Treatments & Carcass & $\begin{array}{c}\text { Abdominal } \\
\text { fat }\end{array}$ & Liver & Pancreas & Gizzard \\
\hline \multicolumn{6}{|l|}{$\overline{\mathrm{A}}$} \\
\hline- & 75.3 & 1.98 & 2.06 & 0.266 & 2.45 \\
\hline+ & 74.1 & 2.17 & 2.25 & 0.286 & 2.59 \\
\hline \multicolumn{6}{|l|}{ B } \\
\hline- & 74.2 & 1.94 & 2.17 & 0.239 & 2.32 \\
\hline+ & 73.8 & 2.03 & 2.11 & 0.258 & 2.37 \\
\hline \multicolumn{6}{|l|}{$\mathrm{C}$} \\
\hline- & 74.3 & 2.01 & 2.17 & 0.264 & 2.03 \\
\hline+ & 73.9 & 2.12 & 2.16 & 0.224 & 2.22 \\
\hline \multicolumn{6}{|l|}{$\mathrm{D}$} \\
\hline- & 74.6 & 1.86 & 2.37 & 0.248 & 2.35 \\
\hline+ & 73.2 & 1.84 & 2.19 & 0.238 & 2.22 \\
\hline Pooled SEM & 1.95 & 0.32 & 0.23 & 0.036 & 0.21 \\
\hline Source of variation & \multicolumn{4}{|c|}{ Probability } & \\
\hline RSM levels & NS & $*$ & $*$ & NS & * \\
\hline enzyme & NS & NS & NS & NS & NS \\
\hline RSM levels $\times$ enzyme & NS & NS & NS & NS & NS \\
\hline \multicolumn{6}{|c|}{$\begin{array}{l}\text { 1-A: control }(0 \% \text { RSM in start } \\
\text { and finisher, respectively; } \\
\text { D - } 15,20 \text { and } 25 \% \text { RSM } \\
{ }^{2} 1000 \mathrm{mg} / \mathrm{kg} \text { multi-enzyme } \\
* \mathrm{P}<0.05\end{array}$} \\
\hline
\end{tabular}


diets $(\mathrm{P}<0.05)$, but carcass yield and pancreas weight were not affected. Feeding high levels of RSM (Treatment D) decreased abdominal fat and gizzard and increased the liver weight of broiler chickens. Carcass characteristics were not affected by enzyme supplementation $(\mathrm{P}>0.05)$.

\section{DISCUSSION}

The present study demonstrates that inclusion of RSM up to 10, 15 and $20 \%$ in the starter, grower and finisher periods, respectively, had no adverse effects on body weight gain or feed conversion ratio. Nevertheless, higher inclusion levels than in treatment D seem not to be suitable for broiler chickens (Table 2 ). The adverse effects of high levels of RSM could be attributed to the amino acid balance of the diet. The reduction of body weight gain may be related to the lysine-arginine imbalance in higher levels of RSM in diets (Roth-Maier et al., 2004). The use of large amounts of RSM is limited because of the lower energy and higher fibre contents compared with SBM. The crude fibre content of RSM negatively affected the AMEn value for broiler chickens (Chibowska et al., 2000). These findings are in agreement with those showing that the inclusion of high levels of CM in broiler diets have adverse effects on broiler chickens performance (Tripathi and Mishra, 2007). Mushtaq et al. (2007) demonstrated that broiler body weight gain was significantly reduced when $30 \% \mathrm{CM}$ was added to the diets during the starter period. Ahmad et al. (2007) reported that CM can be used as up to $20 \%$ of the starter and finisher diets without having any adverse effects on broiler performance. Janjecic et al. (2002) observed in an experiment on broiler chickens that inclusion of low-glucosinolate- and low-erucic acid-RSM up to $20 \%$ of the diet did not affect liveweight compared with chickens fed on SBM; feed efficiency was also not influenced by RSM. The differing results may be related to higher levels of glucosinolate in the meals.

In the present study, feed intake of broilers was not affected by different levels of RSM (Table 2). In agreement with our results, Taraz et al. (2006) found that even complete replacement of SBM with RSM did not affect the feed intake of broilers in the starter and finisher periods. Ahmad et al. (2007) found, however, that feed intake during the starter phase decreased linearly as the dietary CM level $(10,15$ and $20 \%)$ increased. One of the reasons for feed intake reduction with RSM diets is glucosinolates. The glucosinolate content of the RSM used in the present study was low $(8.3 \mu \mathrm{mol} / \mathrm{g})$. Diet palatability can be adversely affected by the glucosinolates of RSM (Mawson et al., 1993), although the influence of flavour on feed intake is less important for poultry than other livestock because the senses of taste and smell among birds are less developed in comparison with other species. 
In this experiment, addition of the multi-enzyme supplement did not affect growth performance but improved protein digestibility in broiler chickens (Table 3). Similarly, Mushtaq et al. (2007) reported that addition of xylanase and $\beta$-glucanase to diets containing 20 and $30 \% \mathrm{CM}$ had no significant effect on feed intake, body weight gain, or feed conversion in broilers. Addition of a multicarbohydrase enzyme supplement to a broiler diet based on wheat, SBM and $\mathrm{CM}$ resulted in a significant improvement in digestibility of protein, starch and NSP (Meng et al., 2005). Kocher et al. (2000) reported that addition of different enzyme preparations to CM-based diets did not alter ileal protein digestibility. The addition of the multicarbohydrase supplement of cell wall-degrading enzymes did not affect performance of broiler chickens fed diets containing maize-SBM or maize-CM (Meng and Slominski, 2005).

The present study demonstrated that inclusion of high levels of RSM decreased abdominal fat and increased liver weight (Table 3). Reduction in abdominal fat content has been observed previously (Janjecic et al., 2002) and may be related to reduction of serum $\mathrm{T}_{3} . \mathrm{T}_{3}$ not only induces intracellular lipid accumulation and various adipocyte specific markers such as malic enzyme and glycerophosphate dehydrogenase, but also stimulates adipocyte cell proliferation and fat cell cluster formation (Yen, 2001). Therefore reduction of serum $\mathrm{T}_{3}$ may decrease the content of abdominal fat. Increasing the ratio of liver weight to live body weight of chickens by RSM has been frequently reported (Kaminska et al., 2000; Janjecic et al., 2002). Hypertrophy of the liver in chickens fed on RSM was probably a consequence of the toxic effects of the hydrolytic products of glucosinolates and may be related to changes in the thyroid. Kahl et al. (2002) showed that changes in the thyroid alter liver size in chickens. Some changes in liver enzymes such as aspartate transaminase, lactate dehydrogenase and alkaline dehydrogenase in the plasma of layers and broilers fed RSM have been reported (Pearson et al., 1983). In the present study, carcass characteristics were not affected by enzyme supplementation. Also Mushtaq et al. (2007) reported that the addition of enzymes had no significant effect on carcass characteristics of broilers fed different levels of RSM.

\section{CONCLUSIONS}

In conclusion, the present study demonstrated that rapeseed meal (RSM) could be used in broiler diets at levels of 10,15 and $20 \%$ in the starter, grower and finisher periods, respectively, but higher levels can impair performance. The addition of a multi-enzyme preparation to diets containing RSM improved protein digestibility but did not affect growth performance of broiler chickens. 


\section{REFERENCES}

Ahmad G., Mushtaq T., Mirza M., Ahmed Z., 2007. Comparative bioefficacy of lysine from L-lysine hydrochloride or L-lysine sulfate in basal diets containing graded levels of canola meal for female broiler chickens. Poultry Sci. 86, 525-530

Annison G., Choct M., 1991. Anti-nutritive activities of cereal non-starch polysaccharides in broiler diets and strategies minimizing their effects. World Poultry Sci. J. 47, 232-242

Chibowska M., Smulikowska S., Pastuszewska B., 2000. Metabolisable energy value of rapeseed meal and its fractions for chickens as affected by oil and fibre content. J. Anim. Feed Sci. 9, 371-378

Fenton T.W., Fenton M., 1979. Determination of chromic oxide in feed and feces. Can. J. Anim. Sci. $58,631-638$

Janjecic Z., Grbeša D., Muzic S., Curic S., Rupic V., Liker B., Dikic M., Antunovic B., Zupanic D., 2002. Influence of rapeseed meal on productivity and health of broiler chicks. Acta Vet. Hung. 50, 37-50

Kahl S., Rosebrough R., Elssaser T., 2002. Hepatic 5' deiodinase activity in the broiler chicken: Effects of diet and prior thyroid status. Nutr. Res. 22, 375-383

Kamińska B.Z., Brzóska F., Skraba B., 2000. High-protein fraction of 00 type rapeseed meal in broiler nutrition. J. Anim. Feed Sci. 9, 123-136

Kaushik N., Agnihotri A., 1999. High performance liquid chromatographic method for separation and quantification of intact glucosinolates. Chromatographia 49, 281-284

Kocher A., Choct M., Porter M.D., Broz J., 2000. The effects of enzyme addition to broiler diets containing high concentration of canola or sunflower meal. Poultry Sci. 79, 1767-1774

Mawson R., Heany R.K., Zduńczyk Z., Kozlowska H., 1993. Rapeseed meal glucosinolates and their antinutritional effects 2. Flavour and palatability. Nahrung 37, 336-344

Meng X., Slominski B.A., 2005. Nutritive values of corn, soybean meal, canola meal and peas for broiler chickens as affected by a multicarbohydrase preparation of cell wall degrading enzymes. Poultry Sci. 84, 1242-1251

Meng X., Slominski B.A., Nyachoti C.M., Campbell L.D., Guenter W., 2005. Degradation of cell wall polysaccharides by combinations of carbohydrase enzymes and their effect on nutrient utilization and broiler chicken performance. Poultry Sci. 84, 37-47

Mushtaq T., Sarwar M., Ahmad G., Mirza M.A., Nawaz H., Haroon Mushtaq M.M., Noreen U., 2007. Influence of canola meal-based diets supplemented with exogenous enzyme and digestible lysine on performance, digestibility, carcass, and immunity responses of broiler chickens. Poultry Sci. $86,2144-2151$

NRC, 1994. Nutrient Requirements of Poultry. National Research Council. 9th Edition. National Academy Press. Washington, DC

Pearson A.W., Greenwood N.M., Butler E.J., Fenwick G.R., 1983. Biochemical changes in layer and broiler chickens when fed on a high glucosinolates rapeseed meal. Brit. Poultry Sci. 24, 417-427

Roth-Maier D.A., Böhmer B.M., Roth F.X., 2004. Effects of feeding canola meal and sweet lupin (L. luteus, L. angustifolius) in amino acid balanced diets on growth performance and carcass characteristics of growing-finishing pigs. Anim. Res. 53, 21-34

SAS, 1997. SAS Users Guide, Version 6.06. Review Edition. Cary, NC

Slominski B.A., Campbell L.D., 1990. Non-starch polysaccharides of canola meal: Quantification, digestibility in poultry and potential benefit of dietary enzyme supplementation. J. Sci. Food Agr. $53,175-184$

Taraz Z., Jalali S.M.A., Rafeie F., 2006. Effects of replacement of soybean meal with rapeseed meal on organs weight, some blood biochemical parameters and performance of broiler chicks. Int. J. Poultry Sci. 5, 1110-1115

Tripathi M.K., Mishra A.S., 2007. Glucosinolates in animal nutrition: A review. Anim. Feed Sci. Tech. $132,1-37$

Yen P.M., 2001. Physiological and molecular basis of thyroid hormone action. Physiol. Rev. 81, 10971142 